\title{
RESEPSI DIALEKTIKA HUKUM ISLAM DENGAN BUDAYA (STUDI ATAS PRAKTEK PEMBAGIAN HARTA WARISAN MASYARAKAT BUMIHARJO DAN SELOMARTO GIRIWOYO WONOGIRI)
}

\author{
Diana Zuhroh, Lila Pangestu Hadiningrum, Andi Cahyono, \\ Instituit Agama Islam Negeri Surakarta \\ Jln. Pandawa, Dusun IV, Pucangan, Kec. Kartasura, Kabupaten Sukoharjo, \\ Jawa Tengah 57168, Indonesia \\ Email :dianazuhroh@yahoo.com, lilahadiningrum@gmail.com, andi_ch@ymail.com
}

\begin{abstract}
Abstrak
Penelitian ini bertujuan untuk mendeskripsikan praktik distribusi warisan di desa Bumiharjo dan Selomarto Giriwoyo Wonogiri, menilai pandangan dan relevansi hukum Islam dalam praktik distribusi warisan di desa Selomarto dan desa Bumiharjo dan menggambarkan relevansi kondisi obyektif dari tradisi pembagian warisan di desa Bumiharjo dan Selomarto dengan hukum keluarganya. Penelitian ini adalah studi lapangan kualitatif dengan menggunakan pendekatan normatif sosiologis. Analisis data menggunakan model MilesHuberman meliputi pengumpulan data, reduksi data, tampilan data, dan penarikan kesimpulan. Dari data di lapangan, ditemukan bahwa praktik mendistribusikan warisan kepada orang-orang Desa Bumiharjo dan Selomarto Giriwoyo Wonogiri dilakukan ketika pewaris masih hidup dan setelah ia meninggal. Sementara praktik membagi warisan setelah pewaris meninggal dilakukan dengan cara gantungan atau penundaan. Dalam kasus-kasus tertentu, di mana anak perempuan mrb keprokon, maka bagian mereka lebih besar daripada anak laki-laki. Praktek membagi warisan dengan lintiran identik dengan hibah, sedangkan praktik cungan identik dengan wasiat. Praktek segendong sepikul relevan dengan ketentuan hukum waris Islam di mana laki-laki mendapat bagian ganda dari bagian perempuan. Praktek membagi warisan secara adil antara pria dan wanita kurang relevan dengan pemahaman dan praktik hukum keluarga di komunitas Bumiharjo dan Selomarto di mana pria bertanggung jawab atas mata pencaharian keluarga.
\end{abstract}

Kata kunci: resepsi, dialektika, hukum Islam, budaya, waris 


\begin{abstract}
This study aims to describe the practice of the distribution of inheritance in the villages of Bumiharjo and Selomarto Giriwoyo Wonogiri, assess the views and relevance of Islamic law in the practice of inheritance distribution in Selomarto and Bumiharjo villages and describe the relevance of the objective conditions of the tradition of inheritance distribution in the villages of Bumiharjo and Selomarto with the law his family. This research is a qualitative field study using a sociological normative approach. Data analysis using the MilesHuberman model includes data collection, data reduction, data display and conclusion drawing. From the data in the field, it was found that the practice of distributing inheritance to the people of Bumiharjo Village and Selomarto Giriwoyo Wonogiri was carried out while the heir was still alive and after he died. While the practice of dividing the inheritance after the testator dies is carried out by means of gantungan or delays. In certain cases, where girls are mokok'i keprabon, then their share is greater than boys. The practice of dividing inheritance with lintiran is identical to a grant, while the practice of cungan is identical to a will. The practice of segendong sepikul is relevant to the provisions of Islamic inheritance law where men get a double share of the women's share. The practice of dividing inheritance equally between men and women is less relevant to the understanding and practice of family law in Bumiharjo and Selomarto communities where men are responsible for family livelihoods.
\end{abstract}

Keywords: reception, dialectics, Islamic law, culture, inheritance 


\section{A. Pendahuluan}

Keuniversalan Islam menunjukkan bahwa kehadirannya tidak hanya diperuntukkan pada satu etnis, golongan atau ras tertentu, tetapi diperuntukan untuk semua manusia, dengan demikian Islam memiliki, daya jangkau dan daya jelajah melampaui batas ruang dan waktu tertentu. Sebagai konsekuensi dari karakteristiknya yang universal tersebut, Islam meniscayakan kemampuan adaptabilitas terhadap lokalitas masyarakat di mana ia diterima. Bahkan dalam ini Islam telah memberikan prinsip-prinsip penting mengenai pengembangan yang rasional dalam upaya adaptasi dengan lingkungan barunya. ${ }^{1}$

Kondisi ini kemudian membuka ruang gerak dialektika antara Islam dengan budaya lokal sebagai dua variabel yang saling berhubungan secara dinamis dan saling mempengaruhi satu sama lain. ${ }^{2}$ ini menunjukkan bahwa dari perspektif teologis, Islam adalah agama dengan sistem nilai dan ajaran yang bersifat ilahiah serta absolut, karena itu ia bersifat transenden. ${ }^{3}$ Sedangkan dari perspektif sosiologis, ia merupakan

1 John Donohue dan John L. Esposito, Pembaharuan Pemikiran dalam Islam, terj. Rajawali (Jakarta: Rajawali Press, 1984), . 72.

${ }^{2}$ Interaksi dari dua variabel ini menghasilkan wujud "akulturasi" sebagai sintesa kreatif dari keduanya, bahkan tidak jarang terjadi pengkoreksian, ketika bentuk kearifan lokal tersebut benar benar bertentangan dengan nilai-nilai Islam yang paling asasi. Begitu juga sebaliknya, Islam (pemikiran keagamaan atau corak Arab-nya) harus melakukan proses mutasi untuk beradaptasi dibawah naungan budaya yang hidup dimasyarakat sepanjang budaya tersebut tidak bertentangan dengan ajaran fundamental dan spirit Islam.

3 Transenden bermakna "di luar segala kemampuan manusia atau lebih utama dan luar biasa". Lihat Departemen Pendidikan Nasional, Kamus Besar Bahasa Indonesia (Jakarta: PT. Gramedia, 2008), . 1484. fenomena peradaban dan kultural dalam realitas manusia. Karena itu, Islam dalam realitas sosial tidak hanya sekedar "doktrin" yang bersifat universal, melainkan juga mengejawantahkan diri dalam institusi-institusi sosial yang dipengaruhi oleh situasi dan kondisi serta terkait dengan dinamika ruang dan waktu. ${ }^{4}$

Dengan demikian, kondisi sosial budaya dan letak geografis menjadi variabel penting yang mempengaruhi perkembangan Islam khususnya "yurisprudensi/hukum Islam". Sebagai kristalisasi reflktif dari penalaran mujtahid atas teks, hukum Islam selalu sarat dengan muatan ruang dan waktu yang melingkupinya. ${ }^{5}$. Maka dari itu hukum Islam (fiqh) akan selalu berkembang dan berubah selaras dengan perkembangan dan perubahan waktu dan ruang yang melingkupinya. ${ }^{6}$

Meskipun demikian, harus pula diakui bahwa perjalanan sejarah menunjukkan adanya bagain-bagian tertentu dalam ajaran Islam yang memunculkan pro-kontra di kalangan masyarakat. Bagian-bagian tersebut, di antaranya, adalah bagian yang menyangkut hukum publik, ${ }^{7}$ yaitu

${ }^{4}$ Pernyataan tersebut mengandung arti bahwa ajaran Islam yang terdiri atas doktrin atau ajaran universal, pada tingkat sosial tidak dapat menghindarkan diri dari perubahan. Lihat Azyumardi Azra, Pergolakan Politik Islam (Jakarta: Paramadina, 1996), . 47.

${ }^{5}$ Sya'ban Muhammad Ismai'il, al-Tasyri' alIslami (Kairo: Maktabat al-nahdlah al-Mishriyyah, 1985), . 16.

6 Ibn al-Qoyyim al-Jauziyyah, I'lam alMuwaqqi'in 'an Rabb al-Alamin (Beirut: Dar alFikr, t.th), . 14. Lihat juga Fazlur Rahman, Neo Modernisme Islam, terj. Mizan (Bandung: Mizan, 1987), . 51. Hasbi ash-Shiddiqie, Falsafah Hukum Islam (Jakarta: Bulan Bintang, 1993), . 444.

${ }^{7}$ Istilah hukum publik itu sendiri diambil dari Abdullahi Ahmed an-Na'im dalam Toward an 
hukum yang berkaitan dengan kepentingan masyarakat, seperti bidang kewarisan. ${ }^{8}$ Pada sisi lain, Islam, yang menuntut ajaran-ajarannya dapat diterapkan di tengah-tengah masyarakat, dapat segera terwujud. Bahkan, agama ini mengharuskan pengikutnya melaksanakan segala ketentuan yang telah ditetapkan Allah dan rasul-Nya, seperti yang dinyatakan dalam alQur'an.

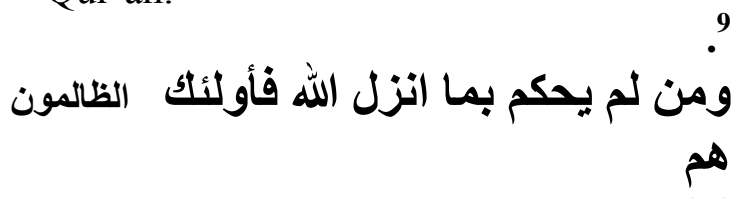

Artinya: "Barangsiapa tidak memutuskan perkara menurut apa yang diturunkan Allah, maka mereka itulah orang-orang yang dzalim. "10

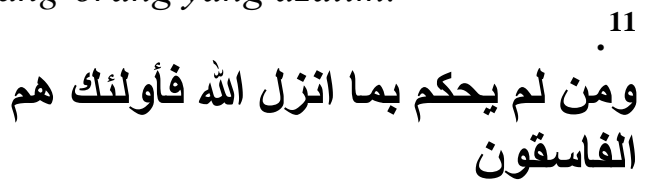

Artinya: "Barangsiapa tidak memutuskan perkara menurut apa yang diturunkan Allah, maka mereka itulah orang-orang yang fasik. ",12

Namun, dalam praktik di masyarakat, ketentuan-ketentuan yang ada tersebut kadang-kadang tidak dapat

Islamic Reformation: Civil Liberties, Human Rights, and International Law, (New York: Syrcuse University Press, 1990),

\footnotetext{
${ }^{8}$ Sementara yang dimaksud dengan hukum itu sendiri menurut E. Utrecht adalah himpunan petunjuk hidup, perintah dan larangan yang mengatur tata tertib dalam suatu masyarakat yang seharusnya ditaati oleh seluruh anggota masyarakat. Oleh karena itu, pelanggaran petunjuk hidup tersebut dapat menimbulkan tindakan (memaksa) oleh pemerintah. C.S.T. Kansil, Pengantar Ilmu Hukum, 37.

${ }^{9}$ Q.S. $5: 45$.

10 Departemen Agama, Syamil Qur'an, (Bandung: CV. Haekal Media Centre, 2007), . 115.

${ }^{11}$ Q.S. 5: 47.

12 Departemen Agama RI, Departemen Agama, Syamil Qur'an, . 115.
}

dijalankan secara sempurna. Penerapan hukum bidang kewarisan di Indonesia, misalnya, ternyata mengalami berbagai hambatan dan benturan, sebagaimana dikemukakan oleh Hazairin. ${ }^{13}$ Menurut Hazairin, sistem hukum kewarisan Islam harus beradaptasi dalam konteks lingkungan Indonesia karena struktur dan sistem kemasyarakatan di Indonesia berbeda dengan latar sosial masyarakat Arab, tempat hukum kewarisan Islam diterapkan. Menurutnya, sistem keluarga atau kekerabatan dalam kewarisan Islam bersifat patriarkal, sedangkan sistem kekerabatan di Indonesia bersifat bilateral.

Produk-produk pemikiran hukum kewarisan Islam di Indonesia, baik yang terdapat dalam fiqh maupun pemikiran para sarjana kontemporer (seperti Hazairin atau fatwa MUI, KHI, dan yurisprudensi) telah mewarnai pola pemahaman, penerapan, dan pelaksanaan hukum Islam yang ada di masyarakat. Realitas tersebut merupakan realitas positif bagi perkembangan dan dinamika hukum Islam pada umumnya, dan hukum kewarisan di Indonesia pada khususnya. Namun, yang menjadi persoalan adalah bagaimana membaca dan memahami dinamika hukum Islam di Indonesia secara baik dan benar, yang sesuai dengan semangat ideal keislaman dalam masyarakat Indonesia.

Dalam konteks kekinian, pemaknaan menjadi penting dalam menghindari lahirnya stigma-stigma

\footnotetext{
${ }^{13}$ Hazairin lahir di Bukit Tinggi pada tanggal
} 28 Nopember 1906 dan meninggal di Jakarta pada tanggal 11 Desember 1975. Pendidikan formalnya dimulai di HIS Bengkulu (1920), kemudian melanjutkan pada MULO di Padang (1926), berikutnya menempuh pendidikan pada AMS di Bandung (1927), RHS di Jakarta (1935) dan terakhir memperoleh gelar Doktor dengan karya penelitian Disertasi berjudul "De Rejang” di Jakarta pada tahun 1936. 
negatif hukum sebagai suatu doktrin yang kaku. Semangat pemaknaan yang terbuka dan moderat dalam setiap gerak hukum adalah semangat universal dalam Islam sebagai rahmatan li al'alamin dan salihun li kulli zamanin wa makan. Spirit itulah yang mengantar proses perkembangan, sistematisasi, dan kodifikasi hukum Islam dalam sejarahnya, sebagaimana tercermin dalam sumbangan Imam Hanafi sebagai sosok, yang secara tekun melakukan proses membangun yang lebih menitikberatkan pada proses sistematisasi atau developing with an increasing measure of systematization. ${ }^{14}$ yang sama juga dilakukan dan disempurnakan oleh generasi sesudahnya, seperti Imam al-Syafi'i dalam bentuk yang lebih sistematis atas jurisprudensi Islam atau systematic form to islamic jurispudence. ${ }^{15}$

Sistem hukum di Indonesia berkembang dan berakar di dalam masyarakat melalui proses yang cukup panjang sebagai hasil dari proses dialektika antara sistem peraturan dan subjek hukum. itu sesuai dengan rumusan dasar hukum yang digagas oleh Aristoteles dan Plato. Menurut keduanya, unsur-unsur pembentuk hukum hanya ada dua macam, yaitu sistem peraturan yang mengikat dan subjek hukum (masyarakat dan hakim). ${ }^{16}$ Pada saat yang sama, proses dialektika tersebut melahirkan sikap

\footnotetext{
${ }^{14}$ Ya'akov Meron, "The Development of Legal Thought in Hanafi Text", dalam Studia Islamica, vol 30, tahun 1971, 74.

${ }^{15}$ Ahmad Hasan, "al-Syafi'i Role in Development of Islamic Jurisprudence" dalam (Ian Edge (ed.) Islamic Law and Legal Theory, (Aldershot: Dartmouth, 1996), . 270.

${ }^{16}$ C.S.T. Kansil, Pengantar Ilmu Hukum dan Tata Hukum di Indonesia, (Jakarta: Balai Pustaka, 1989), . 34.
}

kepatuhan masyarakat, sikap menerima, dan lahirnya sanksi-sanksi ketika masyarakat tidak menerima ketentuan yang berlaku. Pada akhirnya, ini melahirkan sistem peraturan atau sistem hukum di masyarakat. ${ }^{17}$

Salah satu contoh fenomena yang berkaitan dengan problem di atas adalah masyarakat Desa Bumiharjo dan Selomarto Kecamatan Giriwoyo Kabupaten Wonogiri Jawa Tengah. Secara kultural masyarakat Bumiharjo dan Selomarto termasuk masyarakat yang memiliki sifat religius yang cukup tinggi, ini diindikasikan dengan banyaknya sarana-sarana pendidikan agama seperti pondok pesantren dan keteguhan masyarakat Bumiharjo dan Selomarto dalam memegang nilai-nilai formalistik Islam. ${ }^{18}$ Akan tetapi di satu sisi, dalam praktik pembagian harta warisan yang berkembang di daerah tersebut mengikuti adat atau tradisi tersendiri. ${ }^{19}$

Masyarakat Desa Bumiharjo dan Selomarto, mempunyai cara tersendiri dalam menyelesaikan hubungan hukum yang ditimbulkan berkaitan dengan harta seseorang yang meninggal dunia dengan

\footnotetext{
${ }^{17}$ Mengutip pendapat Erich L. Richard, Ade Maman Suherman menjelaskan bahwa sistem hukum utama yang berlaku di dunia berdasarkan pemetaan geografis berlakunya, menjadi enam macam, yaitu: civil law, common law, Islamic law, socialist law, sub-saharan Africa Law dan Far East law. Ade Maman Suherman, Aspek-aspek Hukum Dalam Ekonomi Global,cet. 1 (Jakarta: Gia Indonesia, 2002), . 23-24.

18 Sesuai dengan observasi penulis di Desa Bumiharjo dan Selomarto, bahkan ada yang menyebut Bumiharjo sebagai masyarakat santri karena penduduknya yang cendrung agamis kultural, tak jarang juga tokoh-tokoh agama yang lahir dari daerah Selomarto.

19 ini dijelaskan oleh salah satu warga masyarakat Bumiharjo Wonogiri dalam wawancara penulis dengan Bapak. Sutikno, di kediamannya, 20 Juli 2018. pukul. 18.30 WIB
} 
anggota keluarga yang ditinggalkannya. Masyarakat Bumiharjo dan Selomarto menganut sistem bilateral individual. ${ }^{20}$

Anak laki-laki tertua sebagai pengganti orang tua yang telah meninggal dunia bukanlah pemilik harta peninggalan secara perorangan, ia berkedudukan sebagai pemegang mandat orang tua yang mempunyai kewajiban mengurus anggota keluarga yang lain yang ditinggalkan, termasuk mengurus ibu apabila ayah yang meninggal dan begitu juga sebaliknya, berkewajiban mengurus ayah apabila ibu yang meninggal. Bahkan hasil dari pengamatan penulis di lapangan menegaskan bahwa hak waris perempuan itu dua kali lebih besar dari laki-laki. Fenomena ini menjadi menarik dengan karakter masrakat Bumiharjo dan Selomarto yang religius dengan slogan Keluarga Islam yang harmonis tapi dalam pembagian waris harus bertumpu pada hukum adat setempat.

Berangkat dari fenomena tersebut penulis tertarik untuk meneliti lebih lanjut mengenai praktik pembagian harta warisan dalam masyarakat Desa Bumiharjo dan Selomarto Wonogiri, ini di rasa penting sebagai upaya untuk menemukan relevansi hukum Islam terutama hukum kewarisan dengan hukum adat yang berkembang di masyarakat muslim, dan relevansinya dengan Hukum Keluarga Islam sebagai upaya untuk memperkaya fiqh sebagai diskursus fiqh civil society, merupakan suatu langkah penting untuk memberdayakan fiqh sebagai alat transformasi sosial. ${ }^{21}$

Ada beberapa masalah yang akan dibahas dalam artikel ini, yaitu

\footnotetext{
${ }^{20}$ Soerjono Soekanto, Hukum Adat, . 260.

${ }^{21}$ Zuhairi Misrawi dkk, Islam Negara dan Civil Society, Gerakan dan Pemikiran Islam Kontemporer, (Jakarta: Paramadina, 2005), . 281.
}

bagaimana historisitas sosial antropologis praktik pembagian warisan dalam masyarakat Desa Bumiharjo dan Selomarto Giriwoyo Wonogiri, bagaimana pandangan serta relevansi Hukum Islam dengan praktik pembagian warisan di Desa Bumiharjo dan Selomarto Giriwoyo Wonogiri, dan bagaimana relevansi antara kondisi objektif tradisi pembagian waris di Desa Bumiharjo dan Selomarto Giriwoyo Wonogiri dengan Hukum Keluarga Islam yg diusung masyarakatnya.

\section{B. Pembahasan}

Penelitian tentang praktik pembagian waris dalam masyarakat telah banyak dilakukan oleh para akademisi dan pemikir hukum Islam dengan berbagai sudut pandang baik yuridis normatif maupun dengan pendekatan lain. Di antaranya adalah "Tinjauan Hukum Islam Terhadap Penundaan Pembagian Harta Warisan dalam Hukum Adat dan Pemanfaatannya untuk Keluarga", Umi Maftuhah menyebutkan pembagian warisan setelah seratus hari meninggal karena adanya anggapan dari sebagian masyarakat di Kecamatan Kembaran, dianggap tabu jika harta warisan itu dibagikan sebelum seratus hari meninggalnya pewaris. ${ }^{22}$

Kemudian Abdul im dalam skripsinya yang berjudul "Tinjauan Hukum Islam Terhadap Pelaksanaan Pembagian Warisan Menurut Adat Kecamatan Rembah Kabupaten Kampar Pasir Pangarayan", menulis bahwa pihak perempuan lebih banyak mewarisi daripada pihak laki-laki, rumah dan segala isinya akan dimiliki oleh anak perempuan yang paling kecil dengan

${ }^{22}$ Umi Maftuhah, "Tinjauan Hukum Islam Terhadap Penundaan Pembagian Harta Warisan dalam Hukum Adat dan Pemanfaatannya Untuk Keluarga," Skripsi Pada Fakultas Syari'ah IAIN Sunan Kalijaga Yogyakarta jurusan PA, (2001). 
alasan anak yang paling kecil menjadi penanggung jawab terhadap kakaknya. ${ }^{23}$

Skripsi Mahmud Studi atas "Reaktualisasi Hukum Waris Islam menurut Prof. Dr. H. Munawir Sjadzali, M.A". ${ }^{24}$ Dalam skripsinya, Mahmud mencoba untuk melihat lebih jauh tentang kekuatan reaktualisasi hukum waris Islam bila dihadapkan pada disiplin ilmu Usul Fikih. Menurutnya, pendekatan sosiologis yang dipilih Munawir sebagai kekuatan alternatif dalam menjawab problem kontemporer dapat terus dijaga dan dikembangkan. Demikian juga interpretasi tentang pembagian warisan dalam Islam, tanpa mengkaitkan dengan konteks dan prinsip ruh, teks cenderung terkesan statis. Oleh karena itu reaktualisasi waris harus dilihat dengan memperhatikan kondisi sosial masyarakat sehingga hukum kewarisan Islam bisa tetap diterima.

Kemudian kajian tentang peradilan Islam dalam konteks sosiologis juga dilakukan oleh Daniel S. Lev. Dalam kajiannya tentang pengadilan agama di Indonesia, ia menarik kesimpulan bahwa hukum kewarisan Indonesia dapat dikaji dari tiga sisi, yaitu sisi sosial, politik, dan ideologi. Dari sisi sosial, persoalan kewarisan berangkat dari pertanyaan bagaimana sebenarnya masyarakat Indonesia menyelesaikan masalah kewarisan yang mereka hadapi. Dari sisi politik, pertanyaan dasar yang dikemukakan adalah bagaimana lembaga

23 Abdul im, "Tinjauan Hukum Islam Terhadap Pelaksanaan Pembagian Warisan Menurut Adat Kecamatan Rembah Kabupaten Kampar Pasir Pangarayan," Skripsi pada Fakultas Syari'ah IAIN Sunan Kalijaga Yogyakarta jurusan PA, (1999).

24 Mahmud, “ Studi atas Reaktualisasi Hukum Waris Islam menurut Prof. Dr. H. Munawir Sjadzali, M.A.," Skripsi Fak. Syari'ah IAIN Sunan Kalijaga Yogyakarta, 1998.
Pengadilan Sipil maupun Agama menyelesaikan masalah kewarisan. Sementara itu, aspek ideologis bertitik tolak dari pertanyaan apakah arti ideologis dari masalah kewarisan dalam konstelasi politik dan keragaman kepercayaan di tingkat lokal (daerah) maupun nasional. ${ }^{25}$ Penelitian yang dilakukan oleh Lev tersebut tampaknya masih bersifat umum. Sebaliknya, apa yang dilakukan di sini memfokuskan diri pada putusan-putusan atau yurisprudensi yang dikeluarkan oleh Mahkamah Agung. Dengan demikian, penelitian ini lebih bersifat spesifik. serupa dilakukan oleh David S. Powers. Ia melakukan kajian tentang aspek sosiologis (sosiologi teks) atau, lebih tepatnya, hermeneutika Al-Qur'an tentang ayat-ayat kewarisan. Berpijak dari data sejarah yang menunjukkan adanya pengabaian terhadap aturan hukum kewarisan Islam melalui fatwafatwa yang dikeluarkan oleh ulama di Spanyol dan Afrika Utara pada abad pertengahan, ia menyatakan ${ }^{26}$

Mengapa masyarakat pada waktu itu menghindari hukum kewarisan yang telah memiliki ketetapan dari alQur'an dan yang pada umumnya diyakini sebagai model hukum yang paling canggih dan lengkap? Pertanyaan inilah yang mendorong saya untuk kembali pada teks al-Qur'an dengan metodologi dan penyelidikan yang berbeda sama sekali.

25 Daniel S. Lev, Peradilan Agama di Indonesia, alih bahasa Zaini Ahmad Noeh, (Jakarta: Intermasa, 1986).

26 David S. Powers, Kritik Historis Hukum Kewarisan, alih bahasa Arif Maftuhin (Yogyakarta: LKiS, 2001), . vii. 
Metodologi yang dimaksudkan Powers adalah suatu sistem penafsiran atas berbagai dalil (al-Qur'an dan asSunnah) yang diasumsikan perlu direkonstruksi kembali. Menurutnya, hukum kewarisan yang ada sekarang ini berbeda dengan apa yang ia istilahkan sebagai asal muasal atau bibit munculnya hukum Islam (proto-Islamic law). ${ }^{27}$ Pandangannya menarik untuk ditindaklanjuti sebagai upaya rekontekstualisasi hukum kewarisan Islam di Indonesia dengan memperhatikan realitas sosial yang dihadapi masyarakat muslim Indonesia secara objektif. Upaya tersebut, secara umum, dilakukan atau diupayakan melalui penelitian ini.

Artikel ini akan menganalisa "Resepsi Dialektika Hukum Islam dengan Budaya (Studi Atas Praktik Pembagian HartaWarisan Masyarakat Bumiharjo dan Selomarto Giriwoyo Wonogiri)" dengan menggunakan pendekatan normatif-sosiologis. Datadata primer diperoleh melalui hasil wawancara dengan para tokoh agama dan masyarakat di Desa Selomarto dan Bumiharjo Kecamatan Giriwoyo Kabupaten Wonogiri. Sedangkan data sekunder diperoleh dari literatur-literatur yang berkaitan dengan hukum waris Islam, hukum waris adat, hasil penelitian, dan jurnal. Analisis data menggunakan model Miles-Huberman melalui pengumpulan data, reduksi data, display data, dan penarikan kesimpulan.

Dalam teori hukum waris Islam dijelaskan bahwa pewarisan adalah proses peralihan harta waris yang dilakukan pasca meninggalnya pewaris. Praktik pewarisan berbeda dengan wasiat dan hibah. Wasiat adalah

${ }^{27}$ David S. Powers, Kritik Historis Hukum Kewarisan, alih bahasa Arif Maftuhin, . viii. pemberian seseorang kepada orang lain baik berupa barang, piutang ataupun manfaat untuk dimiliki oleh oarng yang diberi wasiat pasca meninggalnya pewasiat. $^{28}$ Sedangkan hibah adalah pemberian yang dilakukan secara sukarela dalam mendekatkan diri kepada Allah tanpa mengharapkan balasan apapun. $^{29}$ Pelaksanaan hibah terjadi antara pemberi dan orang yang diberi saat pemberi masih hidup, sehingga penerima hibah bisa bertindak hukum atas harta yang telah diterimanya.

Berdasarkan hasil wawancara dengan beberapa tokoh agama dan masyarakat Desa Selomarto dan Bumiharjo didapatkan informasi bahwa pembagian harta waris di kedua desa tersebut mayoritas dilakukan pada saat pewaris masih hidup. ${ }^{30}$ Pada masyarakat Dusun Sanggomo Desa Bumiharjo, praktik pembagian harta waris dilakukan saat pewaris masih hidup dan diberikan pada anak-anak yang sudah berkeluarga. $^{31}$ Salah satu cara yang dilakukan yaitu dengan membangunkan rumah bagi anak yang sudah mentas. ${ }^{32}$ Namun, ada juga sebagian kecil masyarakat yang membagi harta waris setelah pewaris meninggal dunia. ${ }^{33}$

28 As-Sayyid Sabiq, Fikih Sunnah, Terjemah: Mudzakir, (Bandung: Al-Ma'arif, 1987), Jilid 14, . 230.

29 Abdul Aziz Dahlan (ed.), Ensiklopedi Hukum Islam, (Jakarta: Ichitar van Hoeve 1996), . 540.

${ }^{30}$ Nono, Kepala Desa Selomarto, Wawancara Pribadi, 8 Juli 2019, Pukul 09.00-10.00, Misbahuddin, Tokoh Masyarakat/Kepala KUA, Wawancara Pribadi, Pukul 15.30-16.00, Mulyono, Tokoh Agama, Wawancara Pribadi, Sabtu 22 Juni 2019, Pukul 12.45-13.30, Khamdi, Tokoh Agama Dusun Dawung Bumiharjo, Wawancara Pribadi, Pukul 14.15-15.00.

${ }^{31}$ Zainal Abidin, Wawancara Pribadi.

${ }^{32}$ Zainal Abidin, Wawancara Pribadi.

${ }^{33}$ Nur Fauzi, Tokoh Agama, Wawancara Pribadi, Sabtu 22 Juni 2019, Pukul 11.30-12.00. 
Sebagaimana kasus yang terjadi di Dusun Cungkrung, praktik pembagian harta waris dilakukan pasca meninggalnya pewaris. ${ }^{34}$

Berkaitan dengan bagian harta yang diterima oleh ahli waris, al-Qur'an menetapkan bahwa laki-laki mendapatkan bagian waris yang besarnya dua kali lipat dari perempuan. ${ }^{35}$ Ketentuan ini telah disepakati oleh jumhur ulama. Namun demikian, dalam praktik pembagian harta waris yang terjadi pada masyarakat Selomarto dan Bumiharjo, mayoritas masyarakat tidak membedakan bagian waris antara lakilaki dan perempuan. Mereka membagi harta waris sama rata antara anak lakilaki dan perempuan.Pembagian harta waris dilakukan dengan jalan musyawarah keluarga dan tradisi ini sudah berjalan secara turun temurun dari orang tua-orang tua mereka dahulu. ${ }^{36}$

Berbeda dengan praktik membagi sama rata kepada anak laki-laki dan perempuan sebagaimana disebutkan di atas, pada masyarakat Dusun Cungkrung dan sebagian kecil masyarakat Dusun Sanggomo Desa Bumiharjo justru mempraktikkan tradisi pembagian harta waris dengan segendong sepikul. ${ }^{37}$ Tradisi ini diklaim sebagai warisan turun temurun dari leluhur mereka. Yang membedakan dari kedua dusun tersebut

${ }^{34}$ Nur Fauzi, Tokoh Agama, Wawancara Pribadi.

${ }_{36}^{35}$ QS An-Nisa (4): 11.

Nono, Kepala Desa Selomarto, Wawancara Pribadi, 8 Juli 2019, Pukul 09.00-10.00, Misbahuddin, Tokoh Masyarakat/Kepala KUA, Wawancara Pribadi, Pukul 15.30-16.00, Mulyono, Tokoh Agama, Wawancara Pribadi, Sabtu 22 Juni 2019, Pukul 12.45-13.30, Khamdi, Tokoh Agama Dusun Dawung Bumiharjo, Wawancara Pribadi, Pukul 14.15-15.00.

${ }^{37}$ Nur Fauzi, Tokoh Agama, Wawancara Pribadi, Sabtu 22 Juni 2019, Pukul 11.30-12.00 dan Zainal Abidin, Tokoh Masyarakat, Wawancara Pribadi, Pukul 13.45-15.00. yaitu pada waktu pelaksanaannya. Pemberian harta waris pada masyarakat Dusun Cungkrung dilakukan pasca meninggalnya pewaris, ${ }^{38}$ sedangkan pada masyarakat Dusun Sanggomo dilakukan saat pewaris masih hidup dan diberikan kepada anak-anak yang sudah berkeluarga. ${ }^{39}$

Selain praktik pembagian sama rata, segendong sepikul, masyarakat Desa Selomarto dan Bumiharjo menerapkan tradisi pembagian harta waris dengan memberikan bagian yang lebih besar kepada anak yang merawat orang tua. Saat masih hidup, orang tua akan menunjuk salah seorang anaknya untuk merawat mereka. ${ }^{40}$ Anak yang ditunjuk untuk merawat orang tua atau dalam istilah Jawa disebut mokok'i keprabon atau nunggoni keprabon biasanya adalah anak perempuan, karena anak perempuan dianggap telaten dan sabar dalam merawat orang tuanya. Dalam tugasnya merawat orang tua, anak perempuan mendapatkan bagian harta waris lebih banyak dari anak lakilaki. ${ }^{41}$ Menurut Zainal Abidin, anak perempuan ditunjuk oleh orang tua untuk mokok'i keprabon dikarenakan anak laki-laki di Dusun Sanggomo banyak yang merantau ke luar kota untuk bekerja. ${ }^{42}$ Meskipun bagian anak perempuan lebih besar daripada anak laki-laki, namun tidak ada perselisihan yang timbul dari praktik ini..

${ }^{38}$ Nur Fauzi, Wawancara Pribadi.

${ }^{39}$ Zainal Abidin, Wawancara Pribadi.

${ }^{40}$ Zainal Abidin, Ibid, dan Khamdi, Tokoh

Agama Dusun Dawung Bumiharjo, Wawancara Pribadi, Pukul 14.15-15.00.

41 Mulyono, Tokoh Agama, Wawancara Pribadi, Sabtu 22 Juni 2019, Pukul 12.45-13.30.

42 Zainal Abidin, Tokoh Masyarakat, Wawancara Pribadi.

43 Zainal Abidin, Tokoh Masyarakat, Wawancara Pribadi 
Menurut keterangan dari para tokoh agama dan masyarakat di atas, hukum waris Islam belum diterapkan oleh masyarakat Selomarto dan Bumiharjo. Ada beberapa faktor yang melatarbelakangi kondisi ini yaitu kurangnya pengetahuan masyarakat akan hukum waris Islam, tidak ada sosialisasi tentang cara membagi harta waris berdasarkan ketentuan syariat Islam, sulitnya memahami hukum waris Islam karena dianggap sangat rigid dan detail. Oleh karena itu, masyarakat lebih memilih untuk mempraktikkan pembagian harta waris berdasarkan adat atau tradisi turun temurun dengan cara bermusyawarah dan membagi harta waris secara sama rata bagi seluruh ahli waris. $^{44}$

Praktik membagikan harta waris dengan mengkuti tradisi yang sudah ada, telah diterima oleh masyarakat Desa Selomarto dan Bumiharjo. Pertimbangan praktis menerapkan tradisi pembagian waris sewaktu pewaris masih hidup dengan asas musyawarah keluarga dan membagi sama rata antara anak laki-laki dan perempuan adalah demi kerukunan dan kemaslahatan para ahli waris. Karena menurut mereka, selagi tradisi itu diterima dan disepakati oleh para ahli waris dan tidak menimbulkan perselisihan, maka tradisi demikian tetap dipertahankan. ${ }^{45}$

Syariat Islam tentang hukum waris menetapkan bahwa peralihan harta yang terjadi melalui proses kewarisan hanya terjadi setelah meninggalnya pewaris. ini sesuai dengan asas semata karena kematian yaitu proses peralihan harta warisan dari pemilik harta kepada ahli

44 Zainal Abidin, Tokoh Masyarakat dan Misbahuddin, Tokoh Masyarakat, Wawancara Pribadi.

45 Mulyono, Tokoh Agama Dusun Sanggomo, Wawancara Pribadi. warisnya terjadi setelah kematian pemilik harta tersebut. Harta seseorang tidak bisa beralih kepada orang lain dengan nama waris selama orang yang memiliki harta masih hidup. ${ }^{46}$ Namun yang terjadi di kedua desa tersebut, mayoritas orang tua mengalihkan harta kepada anak-anaknya saat orang tua masih hidup. Dalam hukum waris Islam, praktik demikian identik dengan makna hibah. Dan hibah orang tua terhadap anaknya dapat diperhitungkan sebagai warisan. ${ }^{47}$ Praktik menghibahkan harta waris saat pemilik harta masih hidup merupakan tindakan antisipasi yang dilakukan oleh pemilik harta agar nantinya tidak ada perselisihan antar ahli waris terkait masalah harta. Munawir Sadzali menyebutnya dengan tindakan pre-emptive yaitu membagi harta kekayaan kepada anak-anaknya secara merata agar kelak tidak menimbulkan persoalan ketika orang tua meninggal dunia. $^{48}$

Tindakan membagi waris sama rata kepada anak laki-laki dan anak perempuan tersebut secara normatif bertentangan dengan maksud QS anNisa ayat 11 yaitu bahwasannya anak laki-laki mendapatkan bagian dua kali lipat lebih banyak dari anak perempuan. $^{49}$ Jika dipahami dengan seksama bahwa ketentuan bagian lakilaki adalah dua kali bagian perempuan bukan menunjukkan ketidakadilan.

${ }^{46}$ Amir Syarifuddin, Hukum Kewarisan..., . 28.

${ }^{47}$ Pasal 211, Kompilasi Hukum Islam.

48 Pradana Boy Z, Fikih Jalan Tengah: Dialektika Hukum Islam Dan Masalah-Masalah Masyarakat Modern, (Jakarta: PT Grafindo Media Pratama, 2008), .27.

49 “Allah mensyariatkan kepadamu tentang (pembagian pusaka untuk) anak-anakmu, yaitu bagian seorang anak laki-laki sama dengan bagian dua orang anak perempuan..., Departemen Agama, Syamil Qur'an, . 78. 
Ketentuan tersebut menunjukkan kesesuaian antara hak dan kewajiban antara laki-laki dan perempuan serta perbedaan tanggung jawab antara keduanya. ini dikuatkan oleh firman Allah Swt dalam QS an-Nisa ayat 34. ${ }^{50}$

Secara sosiologis, praktik membagi waris dengan jalan musyawarah keluarga menggunakan cara hibah mengikuti adat setempat yang sudah berlangsung lama secara turun menurun. Dalam hukum waris adat Jawa, pembagian harta waris saat pemilik harta masih hidup berlaku secara lintiran, ${ }^{51}$ dan cungan. $^{52}$ Praktik membagi harta waris dengan lintiran dan cungan dilakukan oleh orang tua kepada anak-anaknya saat orang tua masih hidup. ${ }^{53}$ Praktik lintiran biasanya dilakukan oleh orang tua dengan memindahkan sesuatu bagian harta peninggalannya kepada ahli waris tertentu sebagai modal kebendaan bagi ahli waris yang memulai kehidupan rumah tangga dan hidup terpisah dari orang tua. Praktik semacam ini terjadi di Dusun Banceran Desa Selomarto, Dusun Sanggomo dan Dawung Desa Bumiharjo, dimana orang tua

50 "Laki-laki (suami) itu pelindung bagi perempuan (istri), karena Allah telah melebihkan sebagian mereka (laki-laki) atas sebagian yang lain (perempuan), dam karena mereka (laki-laki) telah memberikan nafkah dari hartanya. Maka perempuan-perempuan yang seh, adalah mereka yang taat (kepada Allah) dan menjaga diri ketika (suaminya) tidak ada..." Departemen Agama, Syamil Qur'an, . 84.

51 Lintiran adalah pengalihan kedudukan atau jabatan adat, hak dan kewajiban dan harta kekayaan kepada ahli waris, terutama anak tertua. Lihat Hilman Hadikusuma, Hukum Waris Adat, (Bandung: Citra Aditya Bakti, 2003), . 95.

${ }^{52}$ Cungan adalah berpindahnya penguasaan dan pemilikan atas harta kekayaan sebelum pewaris meninggal dunia dari pewaris kepada ahli waris. Lihat Hilman Hadikusuma, Hukum Waris Adat, . 97.

${ }^{53}$ Hilman Hadikusuma, Hukum Waris Adat .95 . mengalihkan hartanya kepada anaknya yang telah mentas dan hidup terpisah dari orang tuanya. Praktik cungan juga diterapkan oleh sebagian masyarakat yaitu dengan cara penunjukan dan harta baru beralih kepada ahli waris setelah kematian pewaris. Tradisi cungan biasanya diperuntukkan bagi anak yang ditunjuk oleh orang tua untuk merawat mereka. Biasanya, anak perempuan dipilih oleh orang tua untuk merawat mereka atau mokok'i atau nunggoni keprabon. Anak perempuan akan mendapatkan rumah induk sebagai imbalan atas jasa mereka dalam merawat orang tua. ini ditegaskan oleh Zainal Abidin selaku tokoh masyarakat Dusun Sanggomo Desa Bumiharjo. Pasca meninggalnya orang tua, anak perempuan akan memperoleh bagian rumah induk disamping memperoleh bagian harta yang lain. Dalam tradisi cungan, ahli waris baru bisa menguasai dan memiliki harta tersebut setelah orang tuanya meninggal dunia. Tradisi ini identik dengan wasiat dalam hukum waris Islam, karena ada pesan yang disampaikan oleh orang tua kepada anaknya, namun penguasaan hartanya baru terjadi pasca meninggalnya orang tua, sehingga rumah induk tadi bukan menjadi harta warisan lagi tetapi merupakan benda wasiat.

Dalam wasiat kepada ahli waris, Kompilasi Hukum Islam menjelaskan tentang kebolehan wasiat kepada ahli waris dengan syarat disetujui oleh ahli waris yang lain. ${ }^{54}$ Faktanya, para ahli waris menyetujui dan tidak mempermasalahkan praktik di atas. Mereka menyadari bahwa anak yang merawat orang tua pantas mendapatkan haknya melalui wasiat orang tua. Hanya

54 Pasal 195 ayat 3 KHI menyebutkan bahwa wasiat kepada ahli waris berlaku bila disetujui oleh semua ahli waris. 
saja, dalam praktik model cungan seperti di atas, bagian anak perempuan lebih banyak daripada anak laki-laki. Sedangkan wasiat dalam hukum waris Islam dibatasi maksimal sepertiga (1/3) dari harta warisan. Mengacu pada ketentuan Kompilasi Hukum Islam, memberikan wasiat melebihi batas maksimal sepertiga dari harta waris diperbolehkan asal disetujui oleh ahli waris yang lain. ${ }^{55}$

Selain praktik membagi harta waris sewaktu pewaris masih hidup, ada sebagian kecil masyarakat menerapkan tradisi membagi harta waris setelah pewaris meninggal dunia. Biasanya praktik ini dilakukan dengan cara gantungan, yaitu ketika salah satu orang tua meninggal dunia, seperti kasus pembagian harta waris yang terjadi di Dusun Cungkrung dan Sanggomo. Pembagian harta waris dilakukan dengan praktik segendong sepikul. $^{56}$ Praktik segendong sepikul adalah bagian anak laki-laki dua kali lipat bagian anak perempuan. ${ }^{57}$ Dari sudut pandang hukum waris Islam, praktik segendong sepikul identik dengan apa yang dimaksud dalam QS an-Nisa ayat 11 yaitu bahwasannya anak laki-laki mendapatkan bagian dua kali lipat dari anak perempuan.

Dalam perspektif sosiologi hukum, adat merupakan gejala sosial yang terbentuk karena adanya interaksi. ${ }^{58}$ Menurut Soerjono Sukanto, interaksi

55 Pasal 195 ayat 2 KHI menyebutkan bahwa wasiat hanya diperbolehkan sebanyakbanyaknya sepertiga dari harta warisan kecuali apabila semua ahli waris menyetujui.

56 Nur Fauzi, Tokoh Agama Dusun Cungkrung dan Zainal Abidin, Tokoh Masyarakat Dusun Sanggomo.

${ }^{57}$ Hilman Hadikusuma, Hukum Waris Adat, 106.

${ }^{58}$ Beni Ahmad Saebani, Sosiologi Hukum, (Bandung: Pustaka Setia, 2006), . 152. sosial merupakan berbagai hubungan sosial yang dinamis, yang menyangkut hubungan antar individu, antara berbagai kelompok manusia maupun antara individu dengan kelompok manusia. ${ }^{59}$ Terbentuknya adat pembagian waris secara turun temurun dengan jalan musyawarah sewaktu pewaris masih hidup dan membagi rata di antara ahli waris, karena adanya interaksi antara individu (pelaku dalam pembagian waris) dengan individu lain dalam masyarakat dengan cara berkomunikasi.Ada interaksi simbolis antar individu dalam masyarakat yang kemudian menjelma menjadi kebiasaan yang terjadi secara berulang-ulang dan pada akhirnya menjadi adat yang mapan.

Praktik pembagian harta waris pada masyarakat Selomarto dan Bumiharjo di atas didasarkan pada sistem kekerabatan masyarakat Jawa pada umumnya yang menganut kekerabatan bilateral atau parental. Dalam masyarakat bilateral atau parental, setiap orang menghubungkan dirinya dalam keturunan kepada ayahnya maupun ibunya. ${ }^{60}$ Tradisi pembagian harta waris di Desa Selomarto dan Bumiharjo menganut asas bilateral, dimana seorang anak mendapatkan harta warisan dari kedua orang tuanya. Pada masyarakat yang bilateral, harta peninggalan dapat dibagikan kepemilikannya di antara ahli waris. Dalam pandangan Hazairin, ini disebut dengan sistem kewarisan individual. ${ }^{61}$ Karena itu, tradisi membagi harta waris saat pewaris masih hidup merupakan implementasi dari sistem

59 Soerjono Soekanto, Sosiologi Suatu Pengantar, (Jakarta: Raja Grafindo Persada, 2007), . 51.

60 Hazairin, Hukum Kewarisan Bilateral, (Jakarta: Tintamas, 1982), . 11.

61 Hazairin, Hukum Kewarisan Bilateral., 15 
kekerabatan bilateral individual yang ada dalam tradisi masyarakat Jawa.

Dalam struktur masyarakat yang relijius, agama menjadi aturan atau norma yang mengatur kehidupan masyarakat dalam semua aspek kehidupan. Masyarakat Selomarto dan Bumiharjo yang notabene mayoritas muslim dan memiliki tokoh agama yang berlatar belakang pendidikan pesantren lebih cenderung mempraktikkan pembagian harta waris secara adat, tidak menerapkan hukum waris Islam sebagaimana ditetapkan oleh nash AlQur'an dan Sunnah.

Tindakan masyarakat dalam membagikan harta waris secara adat, merupakan bentuk resepsi dialektis antara Islam dengan budaya lokal yang sudah berlangsung lama. Ada interaksi antara Islam sebagai agama mayoritas dengan tradisi lokal yang sudah melembaga di masyarakat. Dalam kondisi demikian, hukum waris adat lebih dominan diterapkan oleh masyarakat. Meskipun secara relijius mereka adalah pemeluk Islam tetapi dalam kewarisan lebih mengikuti dan menerima tradisi atau adat lokal. Dengan kata lain, tingkah laku sosial masyarakat dalam berintegrasi satu sama lain, lebih banyak dipengaruhi oleh norma-norma adat daripada peraturan hukum yang seyogyanya berlaku, ${ }^{62}$ dalam ini yaitu Kompilasi Hukum Islam tentang kewarisan.

Pertimbangan masyarakat dalam mempertahankan tradisi tersebut, menurut mereka didasarkan pada kesepakatan ahli waris yang lain dan selama tidak ada perselisihan yang timbul dari pembagian harta waris, maka hukum waris adat tetap berlaku dalam masyarakat. Membagi harta waris sama

\footnotetext{
62 Soleman Taneko, Hukum Adat (Bandung: Eresco, 1987), . 14.
}

rata antara laki-laki dan perempuan menurut mereka dianggap adil. Demikian juga membagi harta waris kepada anak perempuan lebih besar bagiannya daripada anak laki dalam kasus anak perempuan mokok'i keprabon juga dianggap tindakan yang adil karena anak perempuan memiliki tanggung jawab yang berat untuk menjaga dan merawat orang tua.

Masyarakat Desa Selomarto dan Bumiharjo mayoritas beragama Islam dengan corak masyarakatnya parental atau bilateral. Dalam kehidupan berkeluarga, masyarakat kedua desa tersebut memiliki slogan "keluarga Islam yang harmonis". Di kedua desa tersebut, laki-laki memegang peranan penting dalam keluarga yaitu sebagai pencari dan penanggung jawab nafkah keluarga. Karena tugasnya tersebut, maka dalam hukum waris Islam laki-laki mendapatkan bagian waris yang lebih besar daripada perempuan. Dalam konsep keluarga yang parental atau bilateral, laki-laki dan perempuan memiliki hak yang sama dalam hak waris. Pembedaan bagian mereka semata-mata karena tanggung jawab yang dipikul laki-laki lebih besar dalam menafkahi keluarga dan memberikan mahar pada istrinya. ini sesuai dengan asas keadilan yang berimbang, yaitu bahwa pemberian hak waris itu mempertimbangkan tugas dan tanggung jawab yang dipikulnya, bukan berdasarkan jenis kelamin maupun usianya. ${ }^{63}$ Alasan di atas dilegitimasi oleh firman Allah Swt yang berbunyi:

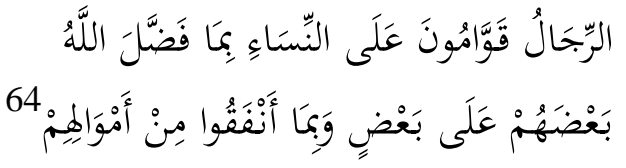

${ }^{63}$ Amir Syarifuddin, Hukum Kewarisan..., .

24.

$$
{ }^{64} \text { QS An-Nisa (4): } 34 .
$$


Artinya:

"Laki-laki (suami) itu pelindung bagi perempuan (istri), karena Allah telah melebihkan sebagian mereka (laki-laki) atas sebagian yang lain (perempuan), dan karena mereka (laki-laki) telah memberikan nafkah dari hartanya. ,65

Ada relasi yang kuat antara perkawinan dan kewarisan. Karena baik dalam perkawinan maupun kewarisan timbul hubungan antara anggota keluarga dimana di dalamnya terdapat suami, istri, anak, dan orang tua. Dalam perkawinan, timbul hak dan kewajiban antara suami dan istri dalam rumah tangga. Suami bertanggung jawab melindungi istrinya dan memberikan segala sesuatu keperluan hidup berumah tangga sesuai dengan kemampuannya. ${ }^{66}$ Dalam kewarisan, masing-masing anggota keluarga memiliki hak yang sama untuk mendapatkan hak waris. Demikian pula yang terjadi pada masyarakat Bumiharjo dan Selomarto, dimana suami (laki-laki) memegang peran penting dalam menafkahi anggota keluarganya. Tanggung jawab ini selaras dengan ketentuan Al-Qur'an, hadis, hukum positif (UU No 1 tahun 1974 dan KHI) yang membebankan tanggung jawab nafkah pada suami. Penerapan praktik segendong sepikul dalam konteks laki-laki sebagai kepala keluarga relevan dengan maksud QS An-Nisa ayat 11 dan hukum positif.

Di sisi lain, masyarakat Bumiharjo dan Selomarto memiliki tradisi yaitu anak perempuan mendapat bagian waris lebih besar daripada anak laki-laki. Tradisi ini hanya kasuistik dimana orang tua memilih salah satu anak perempuannya untuk menjaga

${ }^{65}$ Departemen Agama, Syamil Qur'an, .84.

${ }^{66}$ Pasal 35 Undang-undang Perkawinan No 1 Tahun 1974 (Bandung: Al-Ma'arif, 1976), . 119. mereka di masa tuanya. Karena tanggung jawab inilah maka anak perempuan mendapatkan bagian yang lebih besar daripada laki-laki. Namun ini tidak menimbulkan perselisihan di antara anak-anaknya karena semua menyadari bahwa merawat orang tua adalah tanggung jawab yang berat. Dari aspek ini, tercapai maqashid as-syariah yaitu menjaga jiwa. Menjaga dan merawat orang tua jauh lebih maslahat daripada sekedar memperebutkan harta waris.

\section{Kesimpulan}

Praktik pembagian waris pada masyarakat Desa Bumiharjo dan Selomarto Giriwoyo Wonogiri dilakukan pada saat pewaris masih hidup dan setelah meninggalnya. Praktik membagi waris semasa pewaris masih hidup dilakukan dengan jalan musyawarah keluarga melalui lintiran, dan cungan. Sedangkan praktik membagi waris setelah pewaris meninggal dunia dilakukan dengan gantungan atau penundaan. Cara membagi harta waris dengan tradisi segendong sepikul dan dum dum kupat. Dalam kasus tertentu, dimana anak perempuan mokok' $i$ keprabon (menanggung dan merawat orang tua yang masih hidup) maka bagian mereka lebih besar daripada anak laki-laki.

Praktik pembagian waris dengan model lintiran identik dengan praktik hibah dalam hukum Islam. Sedangkan praktik cungan identik dengan wasiat kepada ahli waris. Membagi harta waris dengan cara segendong sepikul relevan dengan ketentuan hukum waris Islam dimana bagian laki-laki dua kali lipat daripada bagian perempuan. Sedangkan praktik mokok'i keprabon dengan membagikan warisan kepada anak perempuan lebih besar dibanding laki- 
laki lebih mengarah kepada wasiat orang tua saat masih hidup agar anak yang merawat mereka mendapat bagian tambahan berupa rumah dan isinya. Praktik ini tentunya atas kesepakatan ahli waris yang lain.

Tradisi pembagian waris secara sama rata kepada anak perempuan dan anak laki-laki kurang relevan dengan pemahaman dan praktik hukum keluarga di masyarakat Bumiharjo dan Selomarto. Karena dalam masyarakat mereka menganggap bahwa laki-laki adalah penanggung jawab atas nafkah keluarga yang dalam hukum waris Islam seharusnya mendapatkan bagian lebih besar dua kali lipatnya dibandingkan bagian anak perempuan.

\section{Daftar Pustaka}

Abdurrahman, 2001, Kompilasi Hukum Islam di Indonesia, cet. ke-3. Jakarta: CV. Akademika.

Ali, Zainuddin, 2010, Sosiologi Hukum, Jakarta: Sinar Grafika.

al-Jauziyyah, Ibn al-Qoyyim, t.th, I'la $>m$ al-Muwaqqi' $i>n$ 'an Rabb al-A>lami $>n$, Beirut: Dar al-Fikr.

Al-Qur'an, 2007, Syamil Al-Qur'an, Bandung: CV. Haekal Media Centre.

an-Na'im, 1990, Abdullahi Ahmed dalam Toward an Islamic Reformation: Civil Liberties, Human Rights, and International Law, New York: Syracuse University Press.

Arikunto, Suharsimi, 1993, Prosedur Penulisan Suatu Pendekatan Praktik, Jakarta: PT. Rineka Cipta.

ash-Shiddiqie, Hasbi, 1993, Falsafah Hukum Islam, Jakarta: Bulan Bintang.

Azra, Azyumardi, 1996, Pergolakan Politik Islam, Jakarta: Paramadina.
Bekker, Anton dan Ahmad Charis Zubair, 1999, Metodologi Penelitian Filsafat, Yogyakarta: Kanisius.

Boy Z, Pradana Boy Z, 2008, Fikih Jalan Tengah: Dialektika Hukum Islam Dan Masalah-Masalah Masyarakat Modern, Jakarta: PT Grafindo Media Pratama.

Dahlan, Abdul Azis (ed), 1996, Ensiklopedi Hukum Islam, Jakarta: Ichtiar Baru van Hoeve.

Departemen Pendidikan dan Kebudayaan, 1991, Kamus Besar Bahasa Indonesia, Jakarta: Balai Pustaka.

Donohue, John dan John L. Esposito, 1984, Pembaharuan Pemikiran Dalam Islam, terj. Rajawali, Jakarta: Rajawali Press.

Ghulayayni, Musthafa, 1987, Ja>mi' al Duru $<$ s al 'Arabiyah, Beirut: al Maktabah.

Hadikusuma, Hilman, 1993, Antropologi Agama, Bandung: Citra Aditya Bakti.

Waris Adat, Semarang: Adhitya Press.

im, Abdul, 1999, "Tinjauan Hukum Islam Terhadap Pelaksanaan Pembagian Warisan Menurut Adat Kecamatan Rembah Kabupaten Kampar Pasir Pangarayan," Skripsi pada Fakultas Syari'ah IAIN Sunan Kalijaga Yogyakarta Jurusan Peradilam Agama.

Hasan, Ahmad., 1996, al Fara> 'id, cet. ke-14, Surabaya: Pustaka Progressif.

Pr------, 1996, “al-Syafi'i Role in Development of Islamic Jurisprudence" dalam Ian Edge (ed.) Islamic Law and Legal Theory, Aldershot: Dartmouth. 
Hazairin, 1982, Hukum Kewarisan Bilateral, Jakarta: Tintamas.

Humaniora Utama Press, 1992, Kompilasi Hukum Islam di Indonesia, Bandung: Humaniora Utama Press.

Ibrahim, Muhammad Ismail, 1968, Mu'jam al-Alfa<z al Qur'aniyyah, Kairo: Da>r alFikr.

Isma'il,Sya'ban Muhammad, 1985, alTasyri> $\quad$ al-Isla>mi, Kairo: Maktabah al-Nahd $\{$ ah alMis \{riyyah.

Kansil, C.S.T., 1989, Pengantar Ilmu Hukum dan Tata Hukum di Indonesia, Jakarta: Balai Pustaka.

Khamdi, Tokoh Agama Dusun Dawung Bumiharjo, Wawancara Pribadi.

Lev, Daniel S., 1986, Peradilan Agama di Indonesia, alih bahasa Zaini Ahmad Noeh, Jakarta: Intermasa.

Maftuhah, Umi, 2001, "Tinjauan Hukum Islam Terhadap Penundaan Pembagian Harta Warisan dalam Hukum Adat dan Pemanfaatannya Untuk Keluarga," Skripsi Pada Fakultas Syari'ah IAIN Sunan Kalijaga Yogyakarta Jurusan Peradilan Agama.

Mahmud, 1998, "Studi atas Reaktualisasi Hukum Waris Islam menurut Prof. Dr. Munawir Sjadzali, M.A.," Skripsi Fak. Syari'ah IAIN Sunan Kalijaga Yogyakarta.

Makhluf, Hasanain Muhammad, 1976, al Mawa $>r i>s$ fi al Syari>'ah al Isla>miyyah, Mesir: Maktabah Al-Madani.

Meron,Ya'akov, 1971, “The Development of Legal Thought in Hanafi Text", dalam Studia Islamica, Volume 30.
Miles, Matthew B. and A. Michael Huberman, 2014,Terjemah: Tjetjep Rohendi Rohidi, Analisis Data Kualitatif, Jakarta: UI Press.

Misbahuddin, Tokoh Masyarakat/Kepala KUA, Wawancara Pribadi

Misrawi, Zuhairi dkk, 2005, Islam Negara dan Civil Society, Gerakan dan Pemikiran Islam Kontemporer, Jakarta: Paramadina.

Muhajir, Noeng, 2002, Metodologi Penelitian Kualitatif, Yogyakarta: Rake Sarasin.

Mulyono, Tokoh Agama, Wawancara Pribadi.

Nazsir, Nasrullah, 2008, Teori-teori Sosiologi, Bandung: Widya Padjajaran.

Nono, Kepala Desa Selomarto, Wawancara Pribadi.

Nur Fauzi, Tokoh Agama, Wawancara Pribadi.

Powers, David S., 2001, Kritik Historis Hukum Kewarisan, alih bahasa Arif Maftuhin, Yogyakarta: LKiS.

Rahman, Fazlur, 1987, Neo Modernisme Islam, terj. Mizan, Bandung: Mizan.

Rofiq, Ahmad, 1998, Fiqih Mawaris, cet. ke-3, Jakarta: PT Raja Grafindo Persada.

Sabiq, As-Sayyid, 1987, Fikih Sunnah, Terjemah: Mudzakir, Bandung: Al-Ma'arif, Jilid 14.

Saebani, Beni Ahmad dan Encup Supriatna, 2017, Antropologi Hukum, Bandung: Pustaka Setia. , 2006, Sosiologi Hukum,

Bandung: Pustaka Setia.

Sodiqin, Ali, 2013,“Antropologi Hukum Sebagai Pendekatan Dalam Penelitian Hukum Islam", artikel 
dalam Jurnal Manahij, Volume VII, No.1 Januari 2013.

Soekanto, Soerjono, 1988, Pokok-pokok Sosiologi Hukum, Jakarta: RajaGrafindo Persada.

-----------------------, 2007, Sosiologi

Suatu Pengantar, (Jakarta: Raja Grafindo Persada.

Sudjana, Nana dan Ibrahim, 1989, Penelitian dan Penilaian Pendidikan, Bandung: Sinar Baru.

Suherman, Ade Maman, 2002, Aspekaspek Hukum Dalam Ekonomi Global, cet. 1, Jakarta: Gia Indonesia.

Sumino, Tokoh Agama Selomarto, Wawancara Pribadi.
Suprayogo, Imam dan Tobroni, 1991 Metodologi Penelitian SosialAgama, Bandung: Remaja Rosda Karya.

Surakhmad,Winarno, 1990, Pengantar Penelitian Ilmiah: Dasar dan Metode Teknik, Bandung: Tarsio.

Sutrisno Hadi, 1989, Metode Research, Yogyakarta: Andi Offset.

Syarifuddin, Amir, 2004, Hukum Kewarisan Islam, Jakarta: Kencana.

Taneko, Soleman, 1987, Hukum Adat, Bandung: Eresco.

Undang-undang Perkawinan No 1 Tahun 1974 